THURSDAY, APRIL 17, 1873

\section{THE ZOOLOGICAL COLLECTIONS IN THE INDIA HOUSE}

Y former days the "Hon. East India Company," in their House in Leadenhall Street, possessed a valuable Museum of Natural History. It contained specimens in all branches of science from the Company's Oriental possessions, partly contributed by public servants who had been attached as naturalists to missions and deputations sent out by the Indian Government, and partly by gentlemen of the civil and military services of the Company, as presents to the Court of Directors.

The following well-known names were amongst those who contributed to the collection:-Dr. Francis Buchanan Hamilton, Dr. Horsfield, Sir Stamford Raffies, Mr. Wallich, Mr. Reeves, Mr. McClelland, Dr. Helfer, Mr. T. T. Pearson, Dr. Falconer, Mr. Hodgson, Col. Sykes, Mr. Ezra Downes, Gen. Strachey, Col. Tytler, and Dr. Cantor. The list of contributors embraced, in fact, all those naturalists and collectors to whom science is mostly indebted for the knowledge we at present possess of the Fauna of India and the adjoining countries.

Amongst collections of special importance belonging to the East India Museum, may be noticed Dr. Horsfield's collections from Java, those made by Mr. Finlayson during Crawford's Mission to Siam, those of Col. Sykes during his survey at the Dukhun, the entomological collections made by Dr. Cantor in Chusan, and the same naturalist's collections from Singapore; the zoological collections of Sir W. Snow Harris, made during his mission to Abyssinia, and those of Commander Jones during his survey of the Euphrates and Tigris.

In $185 \mathrm{Y}$ the late Dr. Horsfield, who up to the time of his decease was Curator of the Museum, published a catalogue of the mammalia in the collection, which, in addition to an exact enumeration of the specimens, contains many valuable notes upon the habits, range, and other peculiarities of the species. This was followed a few years later by a catalogue of the birds of the collection, which was prepared by Mr. F. Moore, the assistant in the museum, under Dr. Horsfield's superintendence. Of the catalogue of birds two volumes were published, the first in 1854 , and the second in 1858 . The third, which was intended to have completed the work, has never appeared. More than a thousand species, however, are catalogued in the two first volumes, most of them represented by several specimens.

When after the Indian mutiny the absorption of the "Honourable East India Company" by Her Majesty's Government took place, the museum of the Company was moved to Fife House, Whitehall, as a temporary restingplace. The natural history collections were exhibited in this building in a very imperfect way, but it was well understood that they were only deposited here pending the construction of the new India Office, where abundance of space for their display was promised.

The time arrived when the square-towered palace in St. James's Park was finished, and the various branches of the India Office moved into it. So far, however, from there being any more space found for the natural history No. $18 x$-Vor. vir. collections it was now discovered that there was no room for them at all. The whole of them were packed up in boxes and placed in store, and so remain to the present day, so that it is impossible to get at them for any available purpose even when the examination of a particular individual specimen is specially required.

On more than one occasion in the course of scientific work the writer has had occasion to examine sorne of the specimens in the collection, but has been informed that they could not be got at amongst the mass of packages. Other working naturalists have met with similar replies to their applications, and even a Russian entomologist, I have been informed, whose principal motive in coming to England was to examine some of the insects in the collection, had to return with his mission unaccomplished.

In $187 \mathrm{I}$ the late Lieut.-Col. Sykes, having had his attention called to the subject by a letter addressed to the Times, asked the Under-Secretary of State for India in the House of Commons "when the zoological collections in the India House would be accessible to zoologists." The following is stated in the Times of March 15, 1871, to have been the reply given by the Under-Secretary :-

"In reply to my honourable and gallant friend, I have to say that the zoological collections belonging to the Secretary of State in Council, are, to a certain extent, even now available to men of science, who can readily obtain admission to examine them. They examine them however, I am sorry to say, under great difficulties, and difficulties of which I do not see the end : for even if the Secretary of State in Council were to erect on his property in Charles Street, as he has sometimes been advised to do, a building more worthy to contain the great museum and library which he possesses, than the garrets in which they are now stowed away, nearly the whole available space would be occupied by those Indian productions which it is important to bring under the notice of the commercial classes of this country, and pure science would, I fear, come off very badly."

The "certain extent" to which, according to this reply, the collections are "even now available to men of science," may be judged of from what has been already stated. But in fact, it was ultimately admitted by the Under-Secretary, after a little pressure on the part of the questioner, that the collections were "boxed up;" nor has any change been made in their condition since that period.

It must, I think, be obvious to all those who have read the statement above given that a gross wrong has been perpetrated in the present case. When the Imperial Government took possession of the late East India Company's establishment, they were manifestly bound to perform the duties attached to it. To nail up the whole of the natural history collections in closed cases, and deposit them in a cellar is a strange way of accepting the officium cum onere. It is a wrong, not only to the labourers in science who have occasion to consult the collections, but also to the many distinguished officers of the late Company's service, who contributed to form them. The longer the present state of things continues, the greater will the wrong become, as it is almost impossible to prevent the ravages of insects in the case of specimens of natural history of any sort that are stowed away without periodical examination.

It being, however, hopeless to expect that the India C C 
Office, in its present economical fit, will spend the money necessary to build a Museum for the proper exhibition of its collections of manufactures and natural history, the following two solutions of the difficulty may be suggested.

(I) That an arrangement be made with the Commissioners of the Exhibition of 185 I to exhibit the collections at South Kensington, either in one of the existing buildings, or in one to be constructed for that purpose. The French have an "Exposition des Produits des Colonies" in part of the former Palais de l'Industrie in the Champs Elysées, and there is no reason why we should not follow so desirable a precedent.

(2) If this cannot be effected, the whole of the collections should be transferred to the trustees of the British Museum. It is, of course, quite certain that the trustees could not exhibit them, looking to the crowded state of their galleries in Great Russell Street. But at all events they would be thus saved from risk of further deterioration, and might be rendered accessible to working naturalists who have occasion to consult them.

P. L. S.

\section{UNIVERSITY OARS*}

III.

$\mathrm{W}^{\mathrm{s}}$ E have stated that in our opinion the evils of boatracing as now practised are traceable to two causes, Ist to a misconception of the nature of the demands which it makes on the several energies of the body ; and 2nd, to the system of preparation, or, as it is technically called, training, which is undertaken to enable the body to meet these special demands upon its energies.

In our remarks last week we stated at some length wherein lay the first of these misconceptions, namely, in the nature and extent of the effort made by the muscular system and the respiratory and circulatory system, respectively, showing that while the exertion was slight, if not actually inadequate to the requirements of the former, it was both in amount and character severe, if not absolutely dangerous, in the latter.

The origin of the first misconception, and the reason why it should have lived so long, and should still live, we think may be thus explained. When rowing was first adopted by lads at schools and young men at universities as a regular mode of exercise, and friendly matches of speed and dexterity were organised, the boats used, probably, were not greatly different in size, in shape, or in other points of construction, if in any, from those at the time in use by professional watermen; and the manner of rowing was also, very probably, after the waterman's type. If this were the case then rowing furnished abundant exercise, not only to those portions of the rower's frame which still receive a fair share of employment, but to those also which are at present virtually excluded from the task, or have a very inferior part to play in it; for the heavy, bulky, broad and deep boats, clumsy, unwieldy, and unskilfully arranged oars and rowlocks, would necessitate a slow and protracted stroke, and both upper and lower limbs would have their part to play and their work to do in dragging the oar through the water. Gradually, changes and improvements would be introduced, lessening * Continued from p 4 r8. the labour, heightening the art, until art and labour in boat propulsion attained their present positions and proportions, the former reduced to a minimum, the latter standing eminently high : but just in proportion to the prominence of these conditions are its merits as an exercise in an inverse ratio to be estimated. There was plenty of muscular exertion for the whole frame in lugging along the old-fashioned boats. There was little or no distress to heart or lungs in its protracted stroke and deliberate pace. We frankly confess that there would be little in the old style of boat-racing to create and sustain the enthusiasm at present displayed in these contests; and we are expressing no regret at the changes that have taken place, and no wish to return to their primitive, albeit safe conditions : what we do wish is to let rowing remain as it is, nay, to let it pursue its onward course of change and improvement like all other things, but to see if the old order of safety cannot be retained with these advancements, by obtaining from other sources those properties which recent changes have altogether eliminated or reduced to inefficient proportions.

To glance at the reason why the misconception regarding the actual nature of a boat-race as now rowed, should have so long existed, and should still exist, we think it needs only to be pointed out that only quite recently has any really critical inquiry been instituted on the subject, and when the results of this inquiry were made known, they savoured to the oarsman like the prescribed "nasty medicines" to the child; i.e. whatever good they may have been calculated to effect, they were nevertheless unpalatable, and if not actually rejected were at any rate swallowed with dislike. But rowing men are not singular in this respect, in claiming for their favourite exercise, through all its changes, in all its attributes, perfection: they are claiming no more than all enthusiastic votaries of a special exercise claim, and many with less excuse and less right to an indulgent hearing than the oarsman. "It gives exercise to every muscle of the body," say they, "No exercise whatever," we reply, "does this." No single exercise gives more than employment to a portion of the body, and to that portion sometimes a very inadequate share.

The errors involved in the second misconception in a great measure originate in the first, and their nature is revealed, and the manner of their connection explained as we proceed in making ourselves acquainted with it. Thus an oarsman at a given time will be called upon to row a race which will tax his bodily energies such as he knows them, or believes them, to be, to the uttermost; the effort will be quite exceptional in its severity and he therefore desires to prepare for it, to fortify himself for it, by every means in his power. Now it need hardly be said that if he is ignorant of the nature of the demands which the effort will make upon him, he cannot rightly prepare himself for that effort; nay, he may, and probably will, go wrong, for advice will be pressed upon him at all hands, and here at any rate, "In the multiplicity of counsel there is not wisdom." When it is remembered that this preparation or training embraces the administration, or use, of all the material agents which sustain life and give health and strength, it will not be wondered at that mistakes have been made in this direction, and that man should have come to speak 